toward "some sort of framework that is focused more on the broad competencies. Various schools are trying to do that more specifically in the clinical courses. There's been much less movement toward competencies in the basic science courses."

Busing says several Canadian medical schools are also "developing more and more of their objectives in a competency-based manner," although he projects what will ultimately emerge is a "combination" of competency-based and traditional curricula.

A similar standard appears to be the target for medical school admissions. Busing says the ongoing review of medical education will likely include a recommendation that "encourages the diversity of the Canadian population to apply [and] emphasizes the importance of academic standing and rigour." But admission won't rest solely on academic scores; they will also look for candidates with good communication, collaboration and interpersonal skills. "Some of these other qualities are, in our opinion, key attributes of the physicians of the future."

Both Aschenbrener and Busing stress that the competency-based approaches are not prescriptive, but rather a blueprint by which schools can develop new courses that are more "interdisciplinary" and "integrative."

Medical schools can't be forced into anything, Aschenbrener notes. "But what I would say is that with the knowledge explosion that we have, the priority has to be to equip physicians to be skillful learners and motivated learners throughout their professional lifetime. You can't give them everything they need for a lifetime in medical school and residency. So they have to be at a point that they understand the concepts, they have the tools to self-assess, to learn on their own and to integrate new behaviour. And the notion of competencies is focusing on the knowledge skills and attitudes that one uses regularly in your medical practice."

Busing says that the Canadian review will seek a similar collegial shift within Canadian medical schools and to that end, the final report is "being entitled A Collective Vision, because we really want it to be a vision for the future, but not prescriptive, that says you have to institute recommendations 1-10 in the way they are." - Wayne Kondro, CMAJ

DOI:10.1503/cmaj.091197

\title{
British Medical Association pitches for end to management speak, urges use of plain language
}

$\mathrm{T}$ he message was blunt: Enough of the performer-service user relationship.

The British Medical Association has urged the United Kingdom's National Health Service to ditch its management-speak and begin using clearer language, for example, "patient" rather than "client" or "service user."

A motion passed unanimously at the British Medical Association's Consultants Conference on June 3 called on the National Health Service to use plain English, starting with references to a patient, which in common parlance, describes "the person in the partnership between doctors and those who consult them for health care advice or with an illness."

There's been an inexorable move toward management-speak at the National Health Service in recent years, says Dr. Peter Bamber, the West Yorkshire anesthetist who sponsored the motion. "But what really got me going was an internal document which I couldn't at first understand. It took

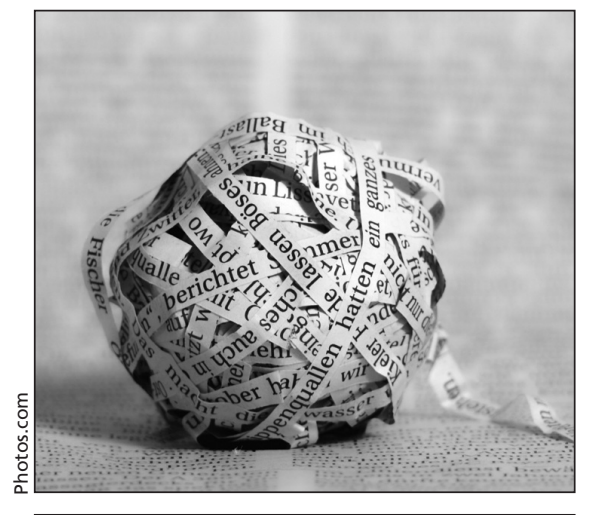

British doctors say the line between gobbledygook and plain English has long since been crossed by the UK's National Health Service.

me several minutes before I realized it was about psychiatric patients and required a response from me. It would have been all too easy just to hit the 'delete' button."

Bamber speculates that referring to patients as "service users" was an attempt to destigmatize illness.

"But if you're ill, you deserve sym- pathy and 'patient' is a word that generates sympathy," he says.

Other examples of jargon in National Health Service documents include the term "performer" for doctor, "efficiency savings and disinvestments" for budget cuts, and a request for volunteers to take part in a "proof of concept" project rather than a pilot project. Some National Health Service patients have received letters informing them that their treatment was "embedded within an indication of needs matrix."

The issue has also drawn the attention of the Plain English Campaign, a UK-based group promoting the use of clear language in public communication, which noted that language confusion among doctors and patients could well become a life or death issue.

While some National Health Service hospitals and trusts have received the Plain English Campaign's annual Crystal Mark for clarity of language, other health institutions have received its notorious Golden Bull award. Last year, the National Health Service 
received a Golden Bull for the following definition of the word 'container': "In relation to an investigational medicinal product, means the bottle, jar, box, packet or other receptacle which contains or is to contain it, not being a capsule, cachet or other article in which the product is or is to be administered, and where any such receptacle is or is to be contained in another receptacle, includes the former but does not include the latter receptacle."

Bamber says his medical colleagues don't object to the medical jargon among doctors. But as with specialized terminology in any profession, such language is often incomprehensible to outsiders, and when addressing a wider audience it is important to use plain English. Bamber adds that while the motion might not end the use of obscure language, "at least now we can say that it is the wish of the medical profession."

In response, the National Health Service issued a statement that it was "working to improve communication." - Mary Helen Spooner, London, England

DOI:10.1503/cmaj.091196

\section{More news at cmaj.ca}

Alzheimer disease: Canadian Institutes of Health Research President Dr. Alain Beaudet unveiled an international Alzheimer program as a prelude to developing a national dementia strategy. - Roger Collier, CMAJ

Cost recovery: Alberta is poised to become the first jurisdiction in the world to sue the convicted for the cost of treating injuries sustained in the commission of a crime. Christie MacLaren, Canmore, Alta.

Baby formula: Critics charge that a probiotic brand of infant formula may have potentially dangerous instructions. Roger Collier, CMAJ

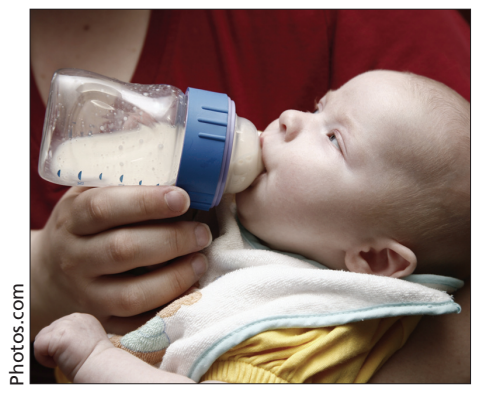

Nasty virus: Infectious disease specialists warn that a major novel $A(H 1 N 1)$ swine flu outbreak may occur in the fall because of the virus' capacity to reassort, possibly with H5N1. - Paul Webster, Toronto, Ont.

Generic drugs: Ontario projects that it will save $\$ 253$ million in 2008/09 with the Transparent Drug System for Patients Act. — Ann Silversides, CMAJ

Recession: The economic recession is projected to increase demand for some medical services, particularly mental health. - Roger Collier, CMAJ

Radiation passport: A University of Toronto radiation resident has developed a \$2.99 iPhone application to calculate cancer risks from medical exams such as computed tomography scans. - Christopher Mason, Ottawa, Ont.

Dispatch: A physician recalls disarming a young patient who entered a hospital with a live grenade. - Yasir Hameed, MD, Taiz, Yemen

Surveillance: The federal government has placed the Canadian Institutes of Health Research in charge of its Drug Safety and Effectiveness Network. Ann Silversides, CMAJ 